\title{
Almond Milk: Preparation, Chemical, Fatty Acids, Mineral, Total Phenolic Compositions and Antioxidant Activity
}

\author{
M. Murat Ceylan (Corresponding author) \\ University of Igdir, Departmant of Food Engineering, Igdir, Turkey \\ E-mail: m.murat.ceylan@igdir.edu.tr \\ Emir Ayse Ozer \\ University of Mustafa Kemal, Departmant of Food Engineering, Hatay, Turkey \\ E- mail: ayseozer@mku.edu.tr
}

\begin{abstract}
The aim of this study was producing a new alternative milk for person who is vegetarian, lactose intolerance sick, cardio-vascular diseased, diabetic or for old people. The dilution fold (3-7) and dilution temperature $\left(25-80{ }^{0} \mathrm{C}\right)$ as producing parameter by pro - tests were carried out. Totally 13 milks were produced. In these conditions, effects of dilution fold and dilution temperature on the proximate, fatty acid, mineral, total phenolic compositions and antioxidant activity of produced milks were investigated.
\end{abstract}

Keywords: Almond milk, Antioxidant activity, Fatty acids composition, Mineral composition, Total phenolic compositions

DOI: $10.7176 / \mathrm{JSTR} / 6-08-11$

\begin{abstract}
1.Introduction
Nowadays, almond milk starts to be a good alternative non - dairy and plant - based beverage in Europe and USA. This miracle milk is prefered especially by people who suffering from diabetes, coeliac artery compression syndome, hypersensitive to cow or sheep or goat milk and lactose intolerance (Anonymous, 2013; Lacono, Lospalluti, Licastro, Scalici and Pediatria, 2008; Salpietro, 2005). Because of containing the important major mineral such as phosphore, magnesium, potassium and calcium, almond milk can make a benefit effect to bones in human body and also by low level sodium, it can be a protector from hypertension (Larsson et al., 2004; Esfahlan, Jamei, 2010; Ahmad, 2010). Many studies show that the consumption of almonds, walnuts, nuts and peanuts have a big role to blance of blood sugar (Jenkins, Kendall et al., 2003; Kendall et al., 2007; Bolling, Dolnikowski, Blumberg, Chen, 2010). And also these kind of foods contain high level of mono - unsaturated and poly - unsaturated fatty acids (Ahmad, 2010). That is the reason why, almond milk can be linked to reduction of the risk of cardiovasculary diseases by decreasing the LDL in blood (Chen, Milbury, Lapsley and Blumberg, 2005). The purpose of this study was to procude a good and benefit plant milk.
\end{abstract}

\section{Materials and methods}

The used materials that raw almond and potable water used in this study were purchased from local market in Hatay, Turkey.

\subsection{Preparation of almond milk}

The response surface method (RSM), that is a kind of experimental design, was used on preparation of almond milk. The dilution fold $(3-7)$ and dilution temparature $\left(25-80{ }^{0} \mathrm{C}\right)$ were chosen as two independent variables (Myers and Montgomery, 2002). The flow chart for RSM is shown in Figure 1. 250 grams of raw almonds were soaked during one night in the potable water at room temperature to obtained a soft skin and remove easily. Water ratio was of 1:4. Dehulled raw almonds were blended with $1 \mathrm{~L}$ of potable water in a $8011 \mathrm{~EB}$ model Waring blender for 5 min A muslin cloth was used as a filter in order to seperate solid particles. Extracted almond milk was pasteurized for $15 \mathrm{~min}$. at $80-85{ }^{\circ} \mathrm{C}$. The flow chart for almond milk is shown in Figure 2. 


\begin{tabular}{|c|c|c|c|c|c|c|}
\hline Variable & Code $-\alpha$ & -1 & $\mathbf{0}$ & +1 & \multicolumn{2}{|l|}{$+\alpha$} \\
\hline Dilution $\quad$ Fold & $\mathrm{X}_{1} \quad 3.0$ & 3.60 & 5.0 & 6.40 & 7.0 & \\
\hline Dilution Temp. & $X_{2} \quad 25.0$ & 33.0 & 52.5 & 72.0 & 80.0 & \\
\hline$-\alpha$ & \multicolumn{2}{|c|}{-1.412} & & & & $+\alpha$ \\
\hline Samples & \multicolumn{3}{|c|}{$\mathbf{X}_{1}$} & \multicolumn{3}{|c|}{$\mathbf{X}_{2}$} \\
\hline 1 & \multicolumn{3}{|c|}{6.4} & \multicolumn{3}{|c|}{72.0} \\
\hline 2 & \multicolumn{3}{|c|}{5.0} & \multicolumn{3}{|c|}{52.5} \\
\hline 3 & \multicolumn{3}{|c|}{6.4} & \multicolumn{3}{|c|}{33.0} \\
\hline 4 & \multicolumn{3}{|c|}{5.0} & \multicolumn{3}{|c|}{80.0} \\
\hline 5 & \multicolumn{3}{|c|}{5.0} & \multicolumn{3}{|c|}{52.5} \\
\hline 6 & \multicolumn{3}{|c|}{5.0} & \multicolumn{3}{|c|}{52.5} \\
\hline 7 & \multicolumn{3}{|c|}{7.0} & \multicolumn{3}{|c|}{52.5} \\
\hline 8 & \multicolumn{3}{|c|}{3.6} & \multicolumn{3}{|c|}{33.0} \\
\hline 9 & \multicolumn{3}{|c|}{5.0} & \multicolumn{3}{|c|}{25.0} \\
\hline 10 & \multicolumn{3}{|c|}{3.0} & \multicolumn{3}{|c|}{52.5} \\
\hline 11 & \multicolumn{3}{|c|}{5.0} & \multicolumn{3}{|c|}{52.5} \\
\hline 12 & \multicolumn{3}{|c|}{3.6} & \multicolumn{3}{|c|}{72.0} \\
\hline 13 & \multicolumn{3}{|c|}{5.0} & \multicolumn{3}{|c|}{52.5} \\
\hline
\end{tabular}

Figure 1: Flow chart for Response surface Method

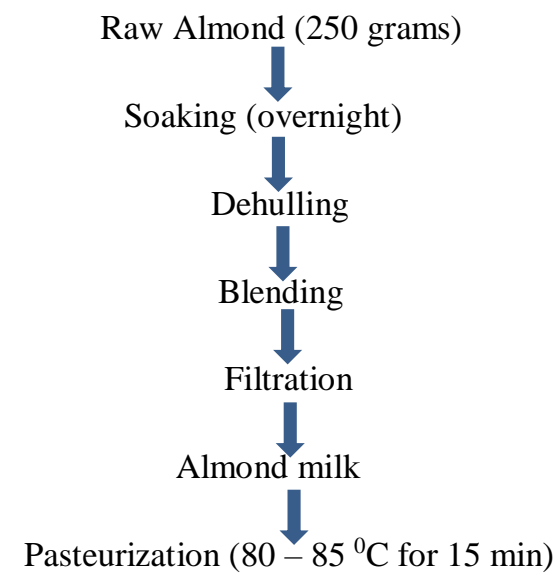

Figure 2: Flow chart for Almond Milk Preparation

\subsection{Chemical compositions}

Dry matter, ash, $\mathrm{pH}$, titratable acidity and crude protein were determined according to standard methods (Anonymous, 1990; Anonymous, 1995). For crude protein, 6,38 was used as conversion factor. Titratable acidity was calculated according to oleic acid. Fat of almond milks was determined by gerber method (Kurt et al., 1996). The amounts of total carbohydrate were obtained by subtracting the amounts of moisture, crude protein, total fat and ash from 100 (Gibson, 1990). 


\subsection{Fatty acid compositions}

Fatty acid composition was determined according to Eder (1995) using a Hewlett-Packerd GC/MS 6890/5972 system with HP-5MS capillary column ( $30 \mathrm{~m} 0.25 \mathrm{~mm}$; $0.25 \mu \mathrm{m}$ film thickness). The carrier gas was helium with a flow of $0.8 \mathrm{ml} / \mathrm{min}$. The split ratio was $1: 10$. The column temperature was programmed at $60-260{ }^{\circ} \mathrm{C}$ with $4{ }^{\circ} \mathrm{C} / \mathrm{min}$. Mass spectra was taken at $70 \mathrm{eV}$. Mass range was from $\mathrm{m} / \mathrm{z}$ $35-350$ amu. For this analysis $2 \mathrm{~mL} 0.5 \mathrm{~N}$ sodiumhyroxide was added on $0.5 \mathrm{~mL}$ almond milk fat. After 2 min heating process, $2 \mathrm{~mL} \mathrm{BF}_{3}$ was added for 2 min heating more. At last $5 \mathrm{~mL}$ hexan was added and shaked to seperate the phasic. Hexan phasic was taken in $2 \mathrm{~mL}$ vial and injectioned into GC/MS (Eder, 1995).

\subsection{Mineral compositions}

$\mathrm{Cu}, \mathrm{Mg}, \mathrm{Fe}, \mathrm{P}, \mathrm{Na}, \mathrm{K}, \mathrm{Zn}, \mathrm{Mn}$ and $\mathrm{Ca}$ were analysed in almond milks. There were some modifications on analysis. $1 \mathrm{~mL}$ almond milk was disposed in microwave tubes. Almond milks were mixed in $8 \mathrm{~mL}$ of $65 \% \mathrm{HNO}_{3}(\mathrm{v} / \mathrm{v})$ and $2 \mathrm{~mL}$ of $30 \% \mathrm{H}_{2} \mathrm{O}_{2}(\mathrm{v} / \mathrm{v})$. All almond milks were burned for $20 \mathrm{~min}$ in microwave oven at $180{ }^{\circ} \mathrm{C}$ (Cem - MARS Xpress). At the end of the 20 min samples were allowed to be cooled and were diluted with ultra-deionized water until $25 \mathrm{~mL}$ level of tubes. In order to seperate solid matters, all solutions were filtered. Mineral composition of almond milk was analysed by inductively coupled plasma atomic emission spectroscopy (ICP - AES; Varian liberty series 2, USA) (Akbulut and Özcan, 2009).

Working conditions of ICP-AES:

Instrument: ICP-AES (Varian-Liberty Series 2)

RF Power: $0.7-1.5 \mathrm{kw}(1.2-1.3 \mathrm{kw}$ for axial)

Plasma gas flow rate (Ar): 10.5-15 L/min. (radial) 15" (axial)

Auxiliary gas flow rate (Ar):1.5"

Viewing height: $5-12 \mathrm{~mm}$

Copy and reading time:1-5 s (max. $60 \mathrm{~s})$

Copy time: $3 \mathrm{~s}(\max .100 \mathrm{~s})$

\subsection{Total phenolic compositions}

Total phenolic compositions of almond milks were determined according to the Folin - Ciocalteu spectrophotometric method with some modifications (Abdulkasım et al., 2007). $20 \%$ of $\mathrm{Na}_{2} \mathrm{CO}_{3}$ as folin reactor, methanol and gallic acid were used for chemical materials and U.V. U - 1900 (Hitachi) spectrofotometer was used for analysis. First of all $5 \mathrm{~mL}$ almond milk was disposed and $5 \mathrm{~mL} 80 \%$ of methanol was added on it. This mixture was centrifugated $4000 \mathrm{xg}$ for $20 \min 100 \mu \mathrm{L}$ of upper layer was taken and mixed with $100 \mu \mathrm{L}$ of Folin - Ciocalteu phenol regant and $3000 \mu \mathrm{L}$ deionized water. Then samples were holded for $10 \mathrm{~min}$ for reaction. At the end of $10 \min 100 \mu \mathrm{L} 20 \%$ of $\mathrm{Na}_{2} \mathrm{CO}_{3}$ was added on samples and holded for 2 hours in darkness to be incubated. After 2 hours of incubation at room temperature, the absorbance at $765 \mathrm{~nm}$ was determined. The measurement was compared to a standard curve of prepared gallic acid (GA) solution and the total phenolic content was expressed as milligrams of gallic acid equivalents (GAE) per gram of dry mater (mg GAE/g dm).

\subsection{Antioxidant activity (DPPH)}

The radical scavenging activity of the almond milk was determined according to method with some modifications (Klimzack et al., 2007). 2.2 - diphenyl - 1 - picrylhydrazly (DPPH) and $80 \%$ of methanol were used as chemical materials and U.V. U - 1900 (Hitachi, Japan) spectrofotometer was used for analysis. As a first step $5 \mathrm{~mL}$ almond milk measured and $5 \mathrm{~mL} 80 \%$ of methanol added on it. This mixture was centrifugated at $4000 \mathrm{xg}$ for $20 \mathrm{~min} 100 \mu \mathrm{L}$ of upper layer was taken and mixed with $2460 \mu \mathrm{L} \mathrm{DPPH}$. This mixture had been allowed to stand in dark for $20 \mathrm{~min}$. At the end of $20 \mathrm{~min}$ the absorbance was measaured at $515 \mathrm{~nm}$ and all samples were read indivially. Inhibition of free radical DPPH in percent (I \%) was calculated in the following way:

$$
I \%=\left(A_{\text {blank }}-A_{\text {sample }} / A_{\text {blank }}\right) \times 100
$$

$A_{\text {blank: }}$ Absorbans value of blank sample which was used $80 \%$ of methanol

$A_{\text {sample: }}$ Absorbance value of each of samples. 


\subsection{Statistical analysis}

The response surface method with two variable and three level central composit design was used to determinate the effects of independent variables on dependent variables for analysis of variance. A regression equation had been determined to show relations between variables. Dilution fold and dilution tempareture had been determined as independent variables for experimental design. Design expert packet of 6.0 program was used for statistical analysis (Montgomery, 2001; Montgomery and Mayers, 2002).

\section{Results and discussions}

\subsection{Chemical compositions}

Chemical compositions of almond milks were summarized in Table 1. Averagely almond milks contained $12.77 \%$ dry matter, $0.43 \%$ ash, $3.21 \%$ crude protein, $6.85 \%$ fat, $2.44 \%$ carbohyrate, $6.62 \mathrm{pH}$ and 5.43 titratable acidity.

Table 1. Chemical compositions of almond milk

\begin{tabular}{lccccccc}
\hline Samples & $\begin{array}{c}\text { Dry matter } \\
(\boldsymbol{\%})\end{array}$ & Ash $(\boldsymbol{\%})$ & $\begin{array}{c}\text { Protein } \\
(\boldsymbol{\%})\end{array}$ & Fat $(\boldsymbol{\%})$ & $\begin{array}{c}\text { Carbohydrate } \\
(\boldsymbol{\%})\end{array}$ & pH & $\begin{array}{c}\text { Titratable acidity } \\
\text { (oleic acid) }\end{array}$ \\
\hline $\mathbf{1}$ & $13.11 \pm 0.03$ & $0.45 \pm 0.01$ & $3.02 \pm 0.01$ & $6.40 \pm 0.02$ & $3.26 \pm 0.02$ & $6.68 \pm 0.02$ & $5.64 \pm 0.03$ \\
$\mathbf{2}$ & $15.11 \pm 0.03$ & $0.52 \pm 0.03$ & $4.21 \pm 0.03$ & $7.30 \pm 0.01$ & $2.49 \pm 0.02$ & $6.57 \pm 0.01$ & $6.70 \pm 0.02$ \\
$\mathbf{3}$ & $11.70 \pm 0.04$ & $0.38 \pm 0.01$ & $2.85 \pm 0.02$ & $6.80 \pm 0.02$ & $1.68 \pm 0.01$ & $6.71 \pm 0.03$ & $5.68 \pm 0.02$ \\
$\mathbf{4}$ & $14.62 \pm 0.02$ & $0.48 \pm 0.01$ & $3.93 \pm 0.01$ & $6.50 \pm 0.02$ & $3.73 \pm 0.02$ & $6.53 \pm 0.02$ & $6.58 \pm 0.01$ \\
$\mathbf{5}$ & $12.67 \pm 0.03$ & $0.43 \pm 0.02$ & $2.93 \pm 0.01$ & $7.50 \pm 0.03$ & $1.82 \pm 0.02$ & $6.63 \pm 0.02$ & $4.18 \pm 0.02$ \\
$\mathbf{6}$ & $10.95 \pm 0.04$ & $0.35 \pm 0.02$ & $2.70 \pm 0.02$ & $6.40 \pm 0.02$ & $2.05 \pm 0.02$ & $6.75 \pm 0.01$ & $4.02 \pm 0.03$ \\
$\mathbf{7}$ & $9.75 \pm 0.02$ & $0.32 \pm 0.01$ & $1.78 \pm 0.02$ & $5.80 \pm 0.03$ & $2.10 \pm 0.02$ & $6.70 \pm 0.01$ & $3.10 \pm 0.02$ \\
$\mathbf{8}$ & $15.10 \pm 0.04$ & $0.50 \pm 0.02$ & $4.19 \pm 0.03$ & $7.40 \pm 0.01$ & $3.91 \pm 0.01$ & $6.50 \pm 0.02$ & $6.74 \pm 0.02$ \\
$\mathbf{9}$ & $9.90 \pm 0.02$ & $0.34 \pm 0.01$ & $1.96 \pm 0.02$ & $6.50 \pm 0.03$ & $1.70 \pm 0.02$ & $6.63 \pm 0.03$ & $4.23 \pm 0.04$ \\
$\mathbf{1 0}$ & $16.50 \pm 0.03$ & $0.58 \pm 0.03$ & $4.60 \pm 0.02$ & $8.0 \pm 0.01$ & $3.37 \pm 0.02$ & $6.43 \pm 0.03$ & $8.34 \pm 0.02$ \\
$\mathbf{1 1}$ & $10.80 \pm 0.04$ & $0.35 \pm 0.02$ & $2.69 \pm 0.01$ & $6.50 \pm 0.03$ & $1.36 \pm 0.02$ & $6.63 \pm 0.02$ & $4.95 \pm 0.02$ \\
$\mathbf{1 2}$ & $15.45 \pm 0.04$ & $0.54 \pm 0.01$ & $4.22 \pm 0.02$ & $7.60 \pm 0.02$ & $3.14 \pm 0.02$ & $6.54 \pm 0.02$ & $6.51 \pm 0.01$ \\
$\mathbf{1 3}$ & $10.35 \pm 0.06$ & $0.35 \pm 0.02$ & $2.65 \pm 0.03$ & $6.30 \pm 0.02$ & $1.15 \pm 0.02$ & $6.76 \pm 0.01$ & $3.97 \pm 0.03$ \\
Average & $\mathbf{1 2 . 7 7}$ & $\mathbf{0 . 4 3}$ & $\mathbf{3 . 2 1}$ & $\mathbf{6 . 8 5}$ & $\mathbf{2 . 4 4}$ & $\mathbf{6 . 6 2}$ & $\mathbf{5 . 4 3}$ \\
\hline & & & & & & &
\end{tabular}

Dry matters of almond milks were determined between $9.75 \%$ and $16.50 \%$ and were determined as averagely $12.77 \%$. According to analysis of variance, the effect of dilution fold had been determined significantly in dry matters $(\mathrm{p}<0.01)$. Increasing of water content caused to reduce the dry matter on almond milks. The linear regression model of relation between two independent factors (dilution fold and dilution temperature) had been shown by an equation with coded factories and real factors for dry matter.

D.M $(\mathrm{C} . \mathrm{F})=12.63-2.72(\mathrm{~A})+1.62(\mathrm{~B})$

D.M (R.F $)=16.728-1.360(\mathrm{~A})+0.054(\mathrm{~B})$

D.M: Dry matter, C.F: Coded factor, R.F: Real factor, A: Dilution fold, B: Dilution temperature

It $\mathrm{s}$ shown that dilution fold was more effective than the dilution temperature and it has been determined as significant $(\mathrm{p}<0.01)$. Three - dimensional graphic of response surface of dilution fold and dilution temperature were shown in Figure 3. According to Figure 3, increasing of dilution fold has caused a decrease in of dry matter linearly. 


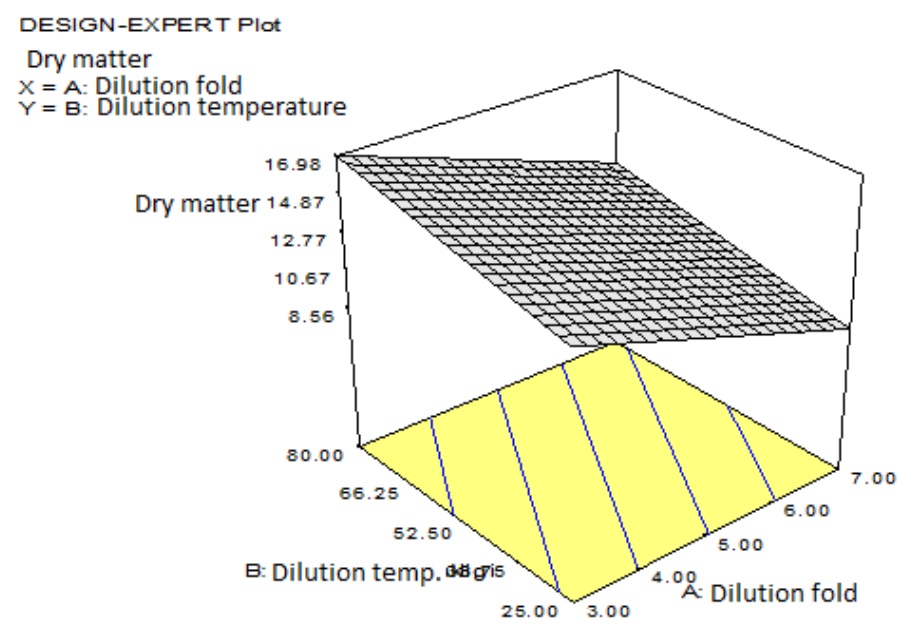

Figure 3: The effect of dilution fold and dilution temperature on dry matter.

Ash of almond milks was determined between $0.32 \%$ and $0.58 \%$ and as average $0.43 \%$. The effect of dilution fold had been determined significantly on ash $(\mathrm{p}<0.05)$. The linear regression model of relation between two independent (dilution fold and dilution temperature) had been shown by an equation with coded factors and real factors for ash.

$\operatorname{Ash}(\mathrm{C} . \mathrm{F})=0.43-0.10(\mathrm{~A})+0.06(\mathrm{~B})$

$\operatorname{Ash}(\mathrm{R} . \mathrm{F})=0.58-0.051(\mathrm{~A})+0.002(\mathrm{~B})$

C.F: Coded factor, R.F: Real factor, A: Dilution fold, B: Dilution temperature

Three - dimensional graphic of response surface of dilution fold and dilution temperature had been shown in Figure 4. According to Figure 4, the increasing of the dilution fold had caused a decreasing in ash value.

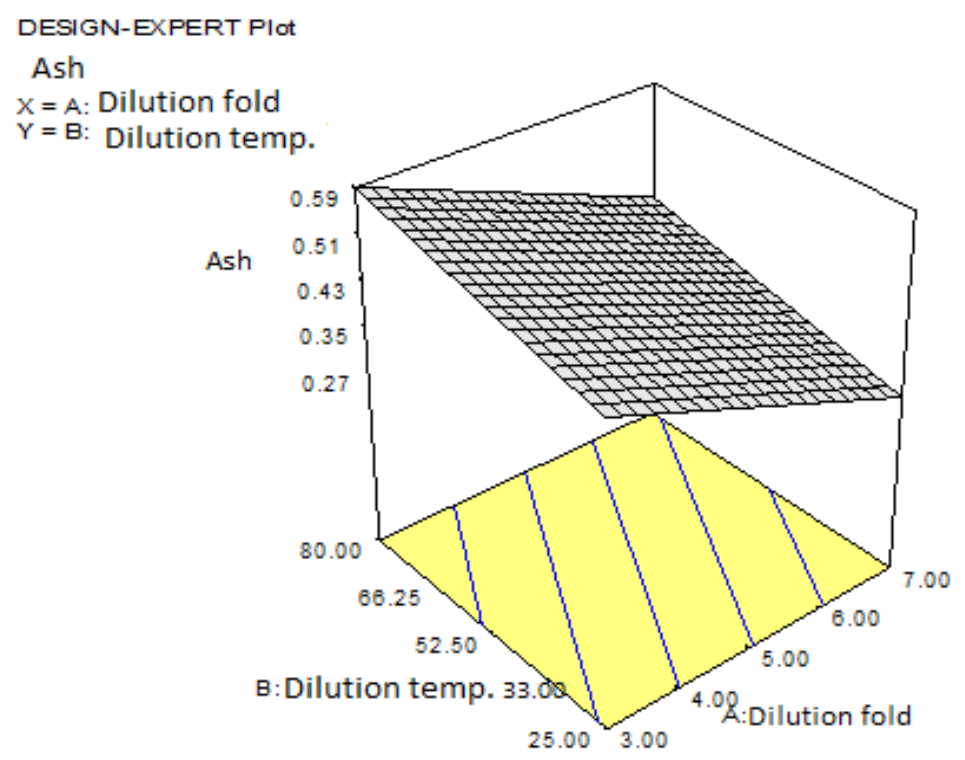

Figure 4: The effect of dilution fold and dilution temperature on ash. 
Proteins of almond milks were determined between $1.78 \%$ and $4.60 \%$ and as average $3.21 \%$. The effect of dilution fold had been determined significant $(\mathrm{p}<0.05)$. The quadratic regression model of relation between two independent factors (dilution fold and dilution temperature) had been shown by an equation with coded factors and real factors for protein.

Protein $(\mathrm{C} . \mathrm{F})=2.99-1.17(\mathrm{~A})+0.54(\mathrm{~B})+0.40\left(\mathrm{~A}^{2}\right)+0.19\left(\mathrm{~B}^{2}\right)+0.08(\mathrm{AB})$

Protein $($ R.F $)=8.37-1.65(\mathrm{~A})+0.009(\mathrm{~B})+0.10\left(\mathrm{~A}^{2}\right)+0.0002\left(\mathrm{~B}^{2}\right)+0.001(\mathrm{AB})$

C.F: Coded factor, R.F: Real factor, A: Dilution fold, B: Dilution temperature

Three - dimensional graphic of response surface of dilution fold and dilution temperature had been shown in Figure 5. According to Figure 5, increasing of the dilution fold had caused a decrease in protein value. This was similar with Figure 3 and Figure 4.

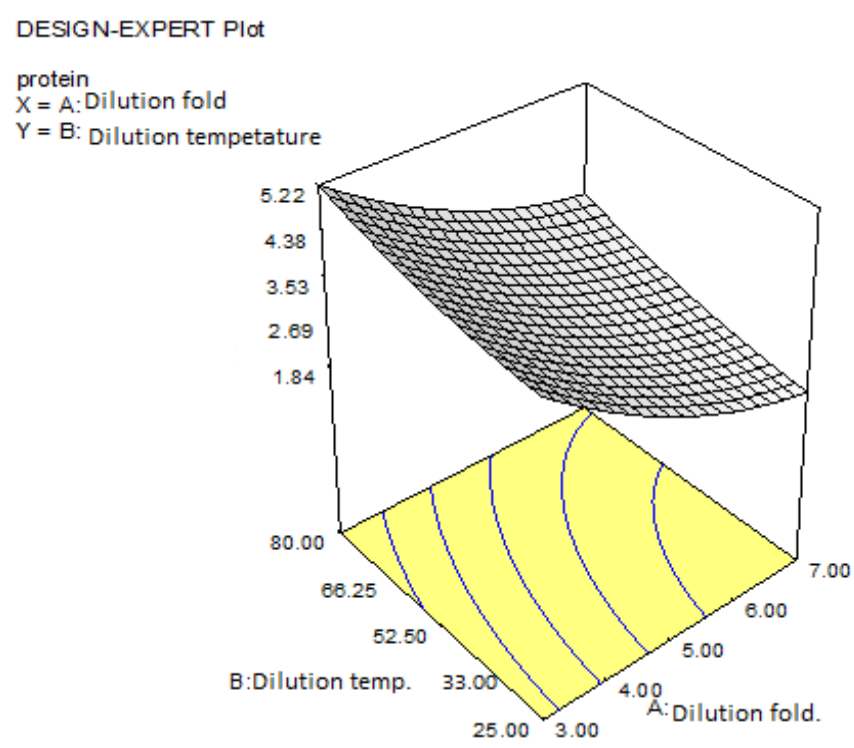

Figure 5: The effect of dilution fold and dilution temperature on protein.

Fat amounts of almond milks were determined between $5.8 \%$ and $8 \%$ and as average $6.85 \%$. The effect of dulition fold had been determined significant on fat $(\mathrm{p}<0.01)$. The linear regression model of relation between two independent factors (dilution fold and dilution temperature) had been shown by an equation with coded factors and real factors for fat.

Fat $(\mathrm{C} . \mathrm{F})=6.85-0.87(\mathrm{~A})-0.039(\mathrm{~B})$

Fat $($ R.F $)=9.098-0.437(\mathrm{~A})-0.001(\mathrm{~B})$

C.F: Coded factor, R.F: Real factor, A: Dilution fold, B: Dilution temperature

Three - dimensional graphic of response surface of dilution fold and dilution temperature had been shown in Figure 6. According to Figure 6, increasing of the dilution fold had caused a decrease in fat value as linearly. 


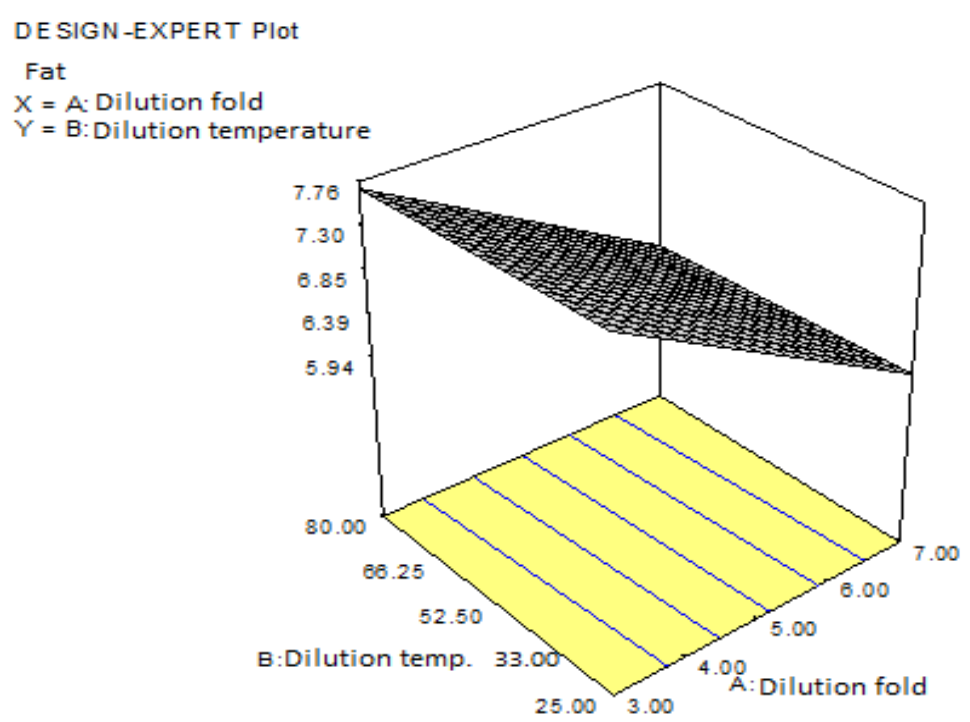

Figure 6: The effect of dilution fold and dilution temperature on fat.

Carbohydrate amounts of almond milk were determined between $1.15 \%$ and $3.91 \%$ and as average determined $2.44 \%$. According to result of variance analysis, the effect of dilution fold had been significant $(\mathrm{p}<0.05)$. The linear regression model of relation between two independent (dilution fold and dilution temperature) had been shown by an equation with coded factors and real factors for carbohydrate.

Carbohydrate $($ C.F $)=2.38-0.69(\mathrm{~A})+0.71(\mathrm{~B})$

Carbohydrate $($ R.F $)=2.94-0.35(\mathrm{~A})+0.024(\mathrm{~B})$

C.F: Coded factor, R.F: Real factor, A: Dilution fold, B: Dilution temperature

Three - dimensional graphic of response surface of dilution fold and dilution temperature had been shown in Figure 7. According to Figure 7, increasing of the dilution fold had caused a decrease in carbohydrate value as linearly.

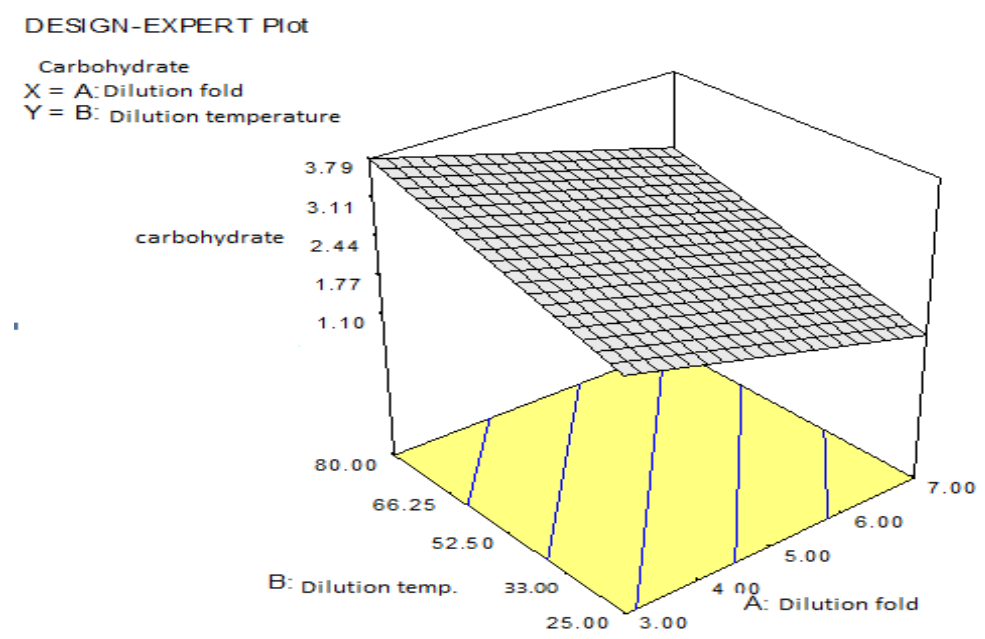

Figure 7: The effect of dilution fold and dilution temperature on carbohydrate.

$\mathrm{pH}$ of almond milks was determined between 6.43 and 6.76 and as average determined $6.62 \%$. According to result of variance analysis, the effect of dilution fold had been significant on $\mathrm{pH} .(\mathrm{p}<0.01)$. The linear 
regression model of relation between two independent factors (dilution fold and dilution temperature) had been shown by an equation with coded factors and real factors for $\mathrm{pH}$.

$$
\begin{aligned}
& \mathrm{pH}(\mathrm{C} . \mathrm{F})=6.62+0.13(\mathrm{~A})-0.03(\mathrm{~B}) \\
& \mathrm{pH}(\mathrm{R} . \mathrm{F})=6.34+0.065(\mathrm{~A})-0.0008(\mathrm{~B})
\end{aligned}
$$

C.F: Coded factor, R.F: Real factor, A: Dilution fold, B: Dilution temperature

Three - dimensional graphic of response surface of dilution fold and dilution temperature had been shown in Figure 8. According to Figure 8, icreasing of the dilution fold had caused a increase in $\mathrm{pH}$ value as linearly.

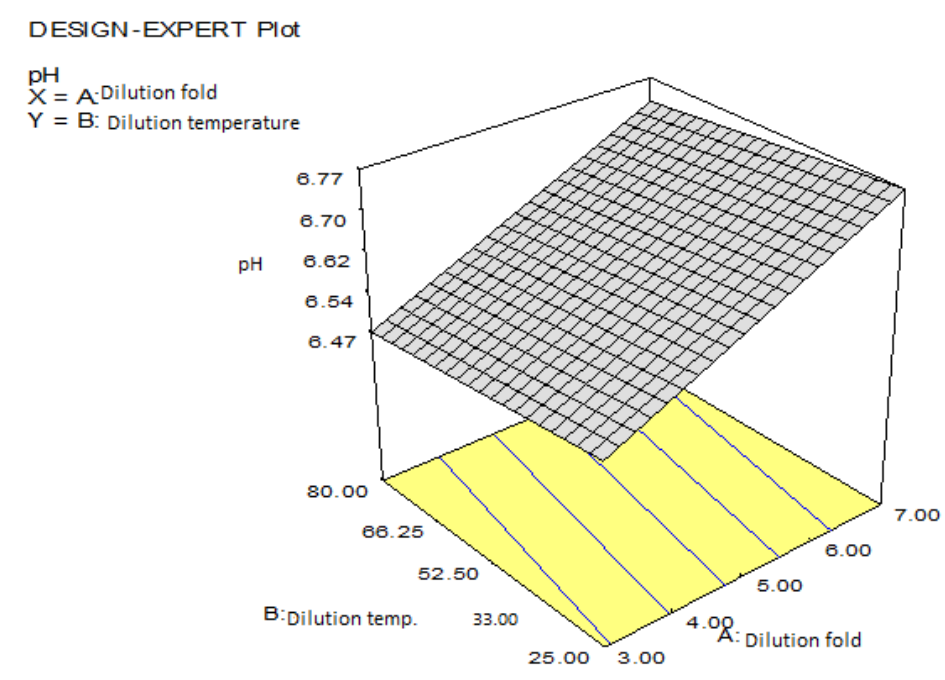

Figure 8: The effect of dilution fold and dilution temperature on $\mathrm{pH}$.

Titratable acidity of almond milks was determined between 3.10 and 8.34 and as average determined 5.43. Titratable acidty was calculated according to oleic acid. According to result of variance analysis, the effect of dilution fold had been significant on titratable acidity. $(\mathrm{p}<0.05)$. The linear regression model of relation between two independent factors (dilution fold and dilution temperature) had been shown by an equation with coded factors and real factorsfor titratable acidity.

Titratable acidity $(\mathrm{C} . \mathrm{F})=5.38-1.66(\mathrm{~A})+0.59(\mathrm{~B})$

Titratable acidity $($ R.F $)=8.57-0.83(\mathrm{~A})+0.02(\mathrm{~B})$

C.F: Coded factor, R.F: Real factor, A: Dilution fold, B: Dilution temperature

Three - dimensional graphic of response surface of dilution fold and dilution temperature had been shown in Figure 9. According to Figure 9, icreasing of the dilution fold had caused a decrease in titratable acidity value as linearly. 


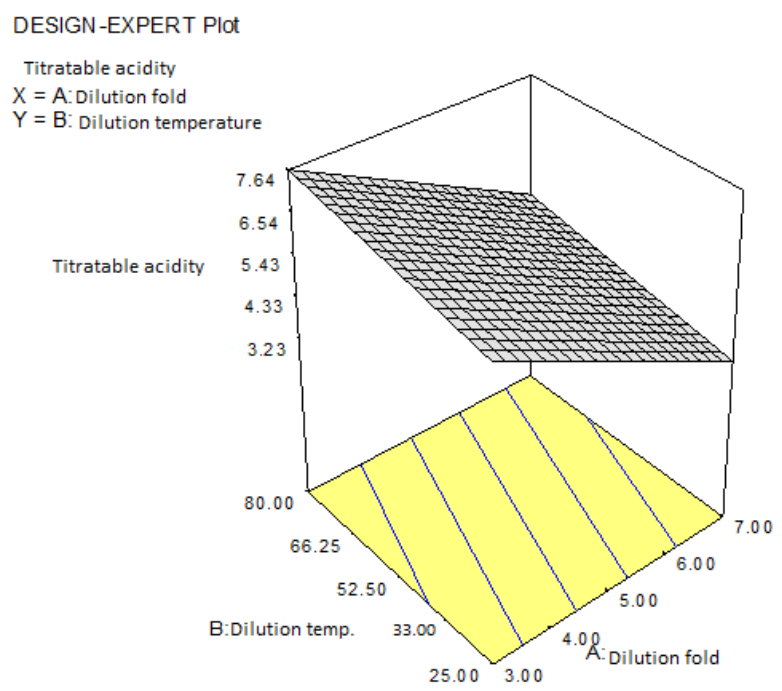

Figure 9: The effect of dilution fold and dilution temperature on titratable acidity.

\subsection{Fatty acid compositions}

Fatty acid compositions of almond milks were summarized in Table 2. According to Table 2, 100mL of almond milk contained about $7.4 \%$ of saturated fatty acid (Palmitic acid 16:0), 65.82\% of mono unsaturated fatty acid (Oleic acid) and $24.45 \%$ of poly - unsaturated fatty acid (linoleic acid) as averagely. Almond milks were analysed for palmitic acid, stearic acid, palmitoleic acid, oleic acid and linoleic acid.

Table 2. Fatty acid composition of almond milk samples (\%)

\begin{tabular}{lccccc}
\hline Samples & C16:0(Palmitic) & C18:0(Stearic) & C16:1(Palmitoleic) & C18:1(Oleic) & C18:2(Linoleic) \\
\hline $\mathbf{1}$ & $7.75 \pm 0.03$ & ND & ND & $64.23 \pm 0.02$ & $24,50 \pm 0,02$ \\
$\mathbf{2}$ & $7.78 \pm 0.05$ & ND & ND & $65.30 \pm 0.05$ & $24.23 \pm 0.01$ \\
$\mathbf{3}$ & $7.67 \pm 0.06$ & ND & ND & $65.45 \pm 0.02$ & $25.05 \pm 0.02$ \\
$\mathbf{4}$ & $7.50 \pm 0.02$ & ND & ND & $64.10 \pm 0.03$ & $24.30 \pm 0.02$ \\
$\mathbf{5}$ & $7.47 \pm 0.01$ & ND & ND & $64.15 \pm 0.02$ & $23.25 \pm 0.03$ \\
$\mathbf{6}$ & $7.78 \pm 0.03$ & ND & ND & $64.15 \pm 0.02$ & $28.06 \pm 0.04$ \\
$\mathbf{7}$ & $7.79 \pm 0.02$ & ND & ND & $68.60 \pm 0.04$ & $23.61 \pm 0.03$ \\
$\mathbf{8}$ & $7.63 \pm 0.04$ & ND & ND & $68.55 \pm 0.01$ & $22.95 \pm 0.05$ \\
$\mathbf{9}$ & $6.48 \pm 0.05$ & ND & ND & $68.70 \pm 0.02$ & $24.81 \pm 0.04$ \\
$\mathbf{1 0}$ & $6.90 \pm 0.03$ & ND & ND & $65.30 \pm 0.03$ & $24.70 \pm 0.03$ \\
$\mathbf{1 1}$ & $7.15 \pm 0.02$ & ND & ND & $63.20 \pm 0.01$ & $24.85 \pm 0.02$ \\
$\mathbf{1 2}$ & $7.12 \pm 0.02$ & ND & ND & $64.50 \pm 0.03$ & $23.68 \pm 0.02$ \\
$\mathbf{1 3}$ & $7.19 \pm 0.01$ & ND & ND & $65.60 \pm 0.02$ & $23.92 \pm 0.01$ \\
Average & $\mathbf{7 . 4}$ & & & $\mathbf{6 5 . 5 3}$ & $\mathbf{2 4 . 4 5}$ \\
\hline
\end{tabular}

ND: Not detected

The main fatty acid of almond milk were oleic, linoleic and palmitic acids (Gallier, Gordon, Singh, 2012). However, Gallier et al. (2012) reported $66.58 \%$ of oleic acid, $5.38 \%$ of palmitic acid, $1.62 \%$ of stearic acid, $0.42 \%$ of palmitoleic acid, $24.34 \%$ of linoleic acid in almond milk which are closed to the values reported in Table 2. But in our study stearic acid and palmitoleic acid were not measured. These diferences may arise from almond cultivars (Miraliakbari and Shahidi, 2008). Fatty acid compositions is very important in the foods because of benefication to people health (Kırbaşlar and Erkmen, 2003). The food which has high amounts of saturated fatty acids might be damage to heart and vasculars (Milner, 2000). By taking these kinds of fatty acids, make the low - density lipid (LDL) augmented in blood. This 
is one of the main factors to catch disease of cardiovascular (Halsted, 2003; Chisholm et al., 2005; Özer, 2007).

\subsection{Mineral compositions}

Mineral compositions of almond milks had been shown in Table 3. Ca, Fe, Mn, Zn, K, Na, P, Cu were determined as mg in $100 \mathrm{~mL}$ almond milk. According to Table 3. $100 \mathrm{~mL}$ almond milk contained averagely $0.051 \mathrm{mg}$ cupper, $15.528 \mathrm{mg}$ magnesium, $0.218 \mathrm{mg}$ ferrous, $16.099 \mathrm{mg}$ phosphor, $2.962 \mathrm{mg}$ sodium, $17.889 \mathrm{mg}$ potassium, $0.162 \mathrm{mg}$ zinc, $0.045 \mathrm{mg}$ manganese and $13.991 \mathrm{mg}$ calcium.

The amounts of potassium, calcium, phosphor and magnesium were higher than other minerals. By the high content of potassium, almond milk can help to blance the pressure of blood and can help to reduce the risk of the arrhythmia (Baysal, 2012). Mineral of calcium has a big role on powerness of bone and teeth. And also by taking sufficient amount of calcium might affect the neural structure, keep cells togetter and on blood coagulation (Ball \& Rutishauser, 1997). Phosphor is a one of important major mineral on enzymes. Also it works togetter with calcium about health of bone and teeth. It s ranged about $90 \%$ in bone and $10 \%$ in cells of whole of phosphor in body (Duyff, 2003). An other important major mineral is magnesium which might take a big role in metabolism, muscles and neural health. However it has an effect on blood pressure (Neyzi and Ertuğrul, 2002).

Table 3. Mineral compositions of almond milks (\%)

\begin{tabular}{|c|c|c|c|c|c|c|c|c|c|}
\hline Samples & $\mathrm{Cu}$ (mg) & $\mathrm{Mg}(\mathrm{mg})$ & $\mathrm{Fe}(\mathrm{mg})$ & $P(m g)$ & $\mathrm{Na}(\mathrm{mg})$ & $\mathrm{K}(\mathrm{mg})$ & $\mathrm{Zn}(\mathrm{mg})$ & $\mathrm{Mn}(\mathrm{mg})$ & $\mathrm{Ca}(\mathrm{mg})$ \\
\hline 1 & $0.05 \pm 0.03$ & $8.51 \pm 0.02$ & $0.11 \pm 0.03$ & $4.96 \pm 0.02$ & $3.06 \pm 0.02$ & $13.63 \pm 0.02$ & $0.08 \pm 0.02$ & $0.04 \pm 0.02$ & $10.74 \pm 0.01$ \\
\hline 2 & $0.04 \pm 0.03$ & $12.30 \pm 0.01$ & $0.04 \pm 0.02$ & $6.00 \pm 0.03$ & $3.34 \pm 0.01$ & $28.47 \pm 0.01$ & $0.04 \pm 0.02$ & $0.04 \pm 0.02$ & $25.10 \pm 0.01$ \\
\hline 3 & $0.03 \pm 0.04$ & $11.22 \pm 0.03$ & $0.18 \pm 0.02$ & $6.49 \pm 0.02$ & $3.04 \pm 0.03$ & $21.64 \pm 0.03$ & $0.04 \pm 0.01$ & $0.03 \pm 0.01$ & $15.06 \pm 0.02$ \\
\hline 4 & $0.04 \pm 0.02$ & $15.79 \pm 0.02$ & $0.12 \pm 0.01$ & $6.17 \pm 0.02$ & $3.38 \pm 0.01$ & $26.67 \pm 0.02$ & $0.01 \pm 0.02$ & $0.05 \pm 0.02$ & $16.04 \pm 0.01$ \\
\hline 5 & $0.03 \pm 0.03$ & $10.54 \pm 0.02$ & $0.34 \pm 0.02$ & $5.61 \pm 0.04$ & $3.33 \pm 0.01$ & $21.11 \pm 0.01$ & $0.08 \pm 0.02$ & $0.04 \pm 0.02$ & $25.21 \pm 0.01$ \\
\hline 6 & $0.10 \pm 0.04$ & $21.26 \pm 0.01$ & $0.07 \pm 0.03$ & $35.10 \pm 0.03$ & $3.46 \pm 0.02$ & $17.66 \pm 0.01$ & $0.11 \pm 0.03$ & $0.03 \pm 0.02$ & $14.12 \pm 0.02$ \\
\hline 7 & $0.02 \pm 0.02$ & $18.66 \pm 0.01$ & $0.07 \pm 0.02$ & $31.55 \pm 0.03$ & $3.41 \pm 0.02$ & $13.75 \pm 0.02$ & $0.05 \pm 0.02$ & $0.04 \pm 0.02$ & $11.84 \pm 0.02$ \\
\hline 8 & $0.01 \pm 0.04$ & $19.07 \pm 0.02$ & $0.12 \pm 0.02$ & $32.99 \pm 0.02$ & $3.57 \pm 0.01$ & $17.47 \pm 0.02$ & $0.10 \pm 0.03$ & $0.03 \pm 0.01$ & $11.91 \pm 0.03$ \\
\hline 9 & $0.04 \pm 0.02$ & $10.20 \pm 0.03$ & $0.07 \pm 0.04$ & $22.45 \pm 0.01$ & $3.28 \pm 0.02$ & $9.14 \pm 0.03$ & $0.02 \pm 0.01$ & $0.06 \pm 0.03$ & $5.57 \pm 0.01$ \\
\hline 10 & $0.05 \pm 0.03$ & $19.48 \pm 0.03$ & $0.66 \pm 0.02$ & $15.16 \pm 0.03$ & $0.51 \pm 0.01$ & $20.74 \pm 0.02$ & $0.22 \pm 0.03$ & $0.03 \pm 0.02$ & $11.64 \pm 0.02$ \\
\hline 11 & $0.07 \pm 0.04$ & $12.69 \pm 0.02$ & $0.11 \pm 0.02$ & $10.62 \pm 0.03$ & $1.36 \pm 0.03$ & $11.84 \pm 0.02$ & $0.20 \pm 0.01$ & $0.06 \pm 0.02$ & $8.41 \pm 0.01$ \\
\hline 12 & $0.06 \pm 0.04$ & $23.95 \pm 0.02$ & $0.64 \pm 0.01$ & $16.67 \pm 0.02$ & $3.55 \pm 0.02$ & $17.40 \pm 0.01$ & $0.42 \pm 0.03$ & $0.03 \pm 0.01$ & $13.46 \pm 0.02$ \\
\hline 13 & $0.04 \pm 0.06$ & $18.20 \pm 0.01$ & $0.27 \pm 0.03$ & $15.4 \pm 0.03$ & $3.17 \pm 0.01$ & $12.98 \pm 0.02$ & $0.68 \pm 0.02$ & $0.05 \pm 0.02$ & $12.71 \pm 0.03$ \\
\hline Average & 0.05 & 15.52 & 0.21 & 16.09 & 2.96 & 17.88 & 0.16 & 0.04 & 13.99 \\
\hline
\end{tabular}

\subsection{Total phenolic compositions and antioxidant activity}

Total phenolic compositions and antioxidant activity of almond milks were shown in Table 4 According to Table 4, total phenolic composition of almond milks was about $0.34 \mathrm{mg} / \mathrm{mL}$ as average and about $67.11 \%$ for antioxidant activity as average. There was no significant effects of independent variables (dilution fold, dilution temperature) on antioxidant activity of almond milks $(\mathrm{p}>0.05)$. At the same time there was no significant the effects of independent variables (dilution fold, dilution temperature) on total phenolic composition of almond milks ( $p>0.05)$. The antioxidant activity of any foods can be explained by chemical composition of food such as phenolic compounds. In other studies reported that some of phenolic compounds may scavenge the free radicals (Apak et al., 2004). 
Table 4. Total phenolic compositions (mg/mL) and antioxidant activity (\%)

\begin{tabular}{ccc}
\hline Samples & $\begin{array}{c}\text { Total phenolic } \\
\text { composition } \\
(\mathbf{m g} / \mathbf{m l})\end{array}$ & $\begin{array}{c}\text { Antioxidant activity } \\
(\mathbf{\%})\end{array}$ \\
\hline $\mathbf{1}$ & $0.172 \pm 0.002$ & $66.02 \pm 0.02$ \\
$\mathbf{3}$ & $0.553 \pm 0.003$ & $72.32 \pm 0.01$ \\
$\mathbf{4}$ & $0.520 \pm 0.001$ & $68.38 \pm 0.01$ \\
$\mathbf{5}$ & $0.414 \pm 0.002$ & $67.74 \pm 0.02$ \\
$\mathbf{6}$ & $0.315 \pm 0.002$ & $66.54 \pm 0.02$ \\
$\mathbf{7}$ & $0.253 \pm 0.003$ & $65.62 \pm 0.02$ \\
$\mathbf{8}$ & $0.154 \pm 0.002$ & $65.35 \pm 0.02$ \\
$\mathbf{9}$ & $0.355 \pm 0.002$ & $66.79 \pm 0.01$ \\
$\mathbf{1 0}$ & $0.396 \pm 0.001$ & $66.95 \pm 0.01$ \\
$\mathbf{1 1}$ & $0.102 \pm 0.001$ & $63.29 \pm 0.01$ \\
$\mathbf{1 2}$ & $0.205 \pm 0.002$ & $66.07 \pm 0.02$ \\
$\mathbf{1 3}$ & $0.403 \pm 0.001$ & $67.05 \pm 0.03$ \\
Average & $0.540 \pm 0.002$ & $70.27 \pm 0.02$ \\
& $\mathbf{0 . 3 4}$ & $\mathbf{6 7 . 1 1}$ \\
\hline
\end{tabular}

\section{Conclusion}

It was thought that; this study may be a homer for producing vegetable milk as alternative to dairy products. Day by day, people take care about healthy nourishment, and people know that healthy nourishment is in direct relationship with health. In this area almond milk does not contain lactose so this maintains to no allergenic effect for the people who has problem with lactose intolerance and diabetes. In the other hand, almond milk does not have any glutens, from this aspect almond milk can be consupted by people who has problem with celiac. In our study, it was determined $65.82 \%$ of oleic acid by this way almond milk might be good at reducing LDL and cardiovascular diseases. We think that, this study can promote to assessment and consuption shape of almond in turkey by this way it can contribute to industry.

\section{References}

Abdulkasim, P., Songchitsomboon, S., Techagumpuch, M., Balee, N., Swatsitang, P., Sungpuag, N., (2007). Antioxidant capacity, total phenolics and sugar content of selected Thai health bevareges. International Journal of Food Sciences and Nutrition, 58(1): 77-85.

Ahmad, Z., (2010). The uses and properties of almond oil. Complementary Therapies in Clinical Practice 16. 10-12

Akbulut, M., Özcan, M., M., (2009). Comparison of mineral contents of mulberry (Morus spp.) fruits and their pekmez (boiled mulberry juice) samples, International Journal of Food Sciences and Nutrition, 60(3), 231-239.

Anonim, (1990). Association of Official Analytical Chemists Official Methods of Analysis (15th ed). Arlington: A. Press.

Anonim, (1995). Association Official Analytical Chemists Official Methods of Analysis (15th ed). Arlington: A. Press.

Anonymous (2013). Plant-based dairy alternatives on the rise. Food ProductDesign [Online] Avaliable: http://www.foodproductdesign.com/news/2013/01/plant-based-dairy-alternativesonthe-rise.aspx (March 5, 2013) 
Apak, R., Güçlü, K., Özyürek, M., Karademir, S., E., (2004). Novel total antioxidant capacity index for dietary polyphenols and vitamins $\mathrm{C}$ and $\mathrm{E}$, using their cupric ion reducing capability in the presence of neocuproine: CUPRAC method. Journal of Agricultural and Food Chemistry, 52, 7970-7981.

Ball, M. and Rutishauser, H., (1997). Food and Nutrition, Wahlquit ML (Ed.), Pages, 335-45.

Baysal, A., (2012). Beslenme. Hacettepe Üniversitesi Sağlık Teknolojisi Yüksek Okulu, Beslenme ve Diyetetik Bölümü. Hatipoğlu Yayınevi Ankara, (495 s).

Bolling, W., Dolnikowski, G., Blumberg, B., Chen, O., (2010). Polyphenol content and antioxidant activity of California almonds depend on cultivar and harvest year. Food Chemistry 122. 819825

Chen, C. Y., Milbury, P. E., Lapsley, K. and Blumberg, J., B., (2005). Flavonoids from almond skins are bioavailable and act synergistically with vitamins $\mathrm{C}$ and $\mathrm{E}$ to enhance hamster and human LDL resistance to oxidation. The Journal of Nutrition, 135(6), 1366-1373.

Chisholm, A., Auley, K., Mann, J., Williams, S., Skeaff, M., (2005). Cholesterol Lowering Effects of Nuts Compared with a Canol a oil Enriched Cereal of Similar Fat Composition. Nutrition, Metabolism and Cardiovascular Diseases. 15, 284-292.

Duyff, R., (2003). Amerikan Diyetisyenler Derneği'nin Geliştirilmiş Besin ve Beslenme Rehberi, Çeviri editörleri: Yücecan S, Pekcan G, Besler T, Nursal B, Acar Matbaacılık, 2003. İstanbul.

Eder, K., (1995). Gaz Chromatographic Analysis of Fatty Asit Methly Esters. J. Chromatog, Biomedical Applications 671: 113- 131.

Esfahlan, A., Jamei, R., (2010). The importance of almond (Prunus amygdalus L.) and its byproducts. Food Chemistry 120. 349-360

Gallier, S., Gordon, K., C., Singh, H., (2012). Chemical and syructural characterisation of almond oil bodies and bovine milk fat globules. Food Chemistry, 132, 1999 - 2006.

Gibson, R. S., (1990). Principles of Nutritional Assessment. Oxford University Press.

Halsted, C.H., (2003). Dietary supplements and functional foods: 2 sides of a coin? American Journal of Clinical Nutrition, 77(suppl ):1001-7.

Jenkins, J. A., Kendall, W. C., Augustine, M., Dorothea, F., Edward, V., Karen, G. Lapsley, A., Tina, L., Robert, G.,Lawrence, A., ve Philip, C., (2003). The Effect of Combining Plant Sterols, Soy Protein, Viscous Fibers, and Almonds in Treating Hypercholesterolemia.

Kendall, W. C., Jenkins J. A., Hu, F. B., Tapsell, L. C., Josse, A. R., (2007). Possible Benefit of Nuts in Type 2 Diabetes. The Journal of Nutrition. 2007 Nuts and Health Symposium.

Kırbaşlar, F. G., Erkmen, G., (2003). Investigation Of the Effect Of Roasting Temperature on the Nutritive Value of Hazelnuts. Plant Foods for Human Nutrition. 58, 1-10

Klimczak, I., Malecka, M., Szlachta, M., Gliszczynska - Swiglo, A., (2007). Effect of storage on the content of Polyphenols, Vitamin C and the Antioxidant Activity of Orange Juice. Journal of Food Composition and Analysis. 20; 313-322.

Kurt, A., Çakmakçı, S., Çağlar, A., (1996). Süt Ürünleri Muayene ve Analiz Metodları Rehberi, Atatürk Üniversitesi Ziraat Fakültesi Yayın No: 18, 208s, Atatürk Üniversitesi Ziraat Fakültesi Ofset Tesisi, Erzurum. 
Lacono, G., Lospalluti, M. L., Licastro, G., Scalici, C., \& Pediatria, I. (2008). A new formula based on almond milk for management of cow milk intolerance and food allergies. Digestive and Liver Disease, 40, A41-A118

Larson, J. D., Wadman, S. A., Chen, E., Kerley, L., Clark, K. J., Eide, M., Lippert, S., Nasevicius, A., Ekker, S. C., Hackett, P. B., Essner, J. J., (2004). Expression of Vecadherin in zebrafish embryos: A new tool to evaluate vascular development. Dev. Dyn. 231(1): 204-213.

Milner, J.A., (2000). Functional Foods: the US perspective. American Journal of Clinical Nutrition;71(suppl):1654-9

Miraliakbari, H., \& Shahidi, F., (2008). Lipid class composition, tocopherols and sterols of tree nut oils extracted with different solvents. Journal of American Oil Chemists' Society,88(4), 81 - 96.

Montgomery, C., Myers, H., (2002). Response Surface Methodology: Process and Product Optimization Using Designed Experiments Vol. 376.

Montgomery, D. C., (2001). Design and Analysis of Experiment. Fifth Edition.

Myers, R.H., Montgomery, D. C., (2002). Response Surface Methodology. Process and Product Optimization Using Design Experiments., A Wiley Inter-Science Publication, 792 p.

Neyzi, O., \& Ertuğrul, T., (ed.) (2002). Pediatri Cilt1, 3.baskı, Nobel Tıp Kitabevi, İstanbul.

Salpietro, C. D. (2005). The almondmilk: A newapproach to themanagement of cow-milk allergy intolerance in infants. Minerva pediatrica, 57(4), 173-180. 